Gut, 1969, 10, 285-292

\title{
Sclerodermatous involvement of the stomach and the small and large bowel
}

\author{
R. D. G. PEACHEY, B. CREAMER, AND J. W. PIERCE \\ From St Thomas' Hospital, London
}

Although scleroderma was first described as a disease of the skin in the eighteenth century it was not until the early part of this century that it gradually became apparent that other organs could also be involved by the disease process.

In 1944 Hale and Schatzki showed that barium swallow examination was abnormal in 13 of 22 patients with scleroderma. They also found four patients out of 18 whose duodenum and upper small intestine were dilated with marked delay in transit of barium. This they attributed to sclerodermatous involvement of the small bowel and could find only one previous similar case reported (Rake, 1931). In 1945 Goetz reported a further five cases with radiological evidence of dilatation of the duodenum and of loops of the small intestine. In recent years the high incidence of oesophageal involvement in scleroderma has become common knowledge. At the same time there have been increasing clinical reports of sclerodermatous involvement of the stomach and small and large bowel. Rosenthal (1957) was able to find 30 cases of small bowel scleroderma in the literature and added one case of his own with steatorrhoea. More recently a number of further cases have been reported and reviews of gastrointestinal involvement in this condition have been published by Goldgraber and Kirsner (1957), Monroe and Knauer (1962), Hoskins, Norris, Gottlieb, and Zamcheck (1962), Sackner (1966), and others.

Although it is now apparent that clinical involvement of the small and large bowel in scleroderma is not uncommon, it is still regarded by many as a rare manifestation of the disease and the wide variation and typical features of the clinical picture have not been sufficiently emphasized in the literature. We therefore reviewed the clinical manifestations of scleroderma involving parts of the gastrointestinal tract other than the oesophagus as seen in 10 patients investigated at this hospital in recent years in order to illustrate some of the predominant clinical features of this condition.

\section{CASES AND METHODS}

The 10 cases of scleroderma, nine of them in women, with evidence of gastric, small bowel, or large bowel involvement have all been investigated at this hospital in the last six years.

Full haematological and biochemical investigations were carried out using conventional techniques. Small bowel meal examinations were performed on all the patients using a dilute barium technique (4 oz of Micropaque made up to 1 pint with cold tap water). Barium enema examinations were carried out on five patients using routine methods. Delayed films of the small bowel meal showing barium outlining the colon were available in three other patients. Case E.N. has already been reported by McBrien and Lockhart Mummery (1962).

RESULTS

The clinical manifestations of gastrointestinal scleroderma and the results of investigation in the 10 cases are summarized in Tables I, II, and III. Of the 10 patients, the skin was involved in nine, eight suffered with Raynaud's phenomenon, and six had typical oesophageal changes on barium examination. One patient (case L.T.) had no manifestation of scleroderma other than malabsorption and a grossly abnormal small bowel meal. Some degree of weight loss was present in all of the patients, and in several, especially those with diarrhoea, malabsorption, or vomiting, this was severe.

The cause of death in the six patients who died is shown in Table I. In three of these scleroderma involving the gastrointestinal tract was directly or indirectly responsible for death.

STOMACH Barium examination showed that although the rate at which the stomach began to empty was usually normal, in five of the 10 cases small amounts of barium remained in the stomach for a long time-in one case for over 24 hours. Gastric dilatation was not a marked feature and 
TABLE I

SUMMARY OF CLINICAL FEATURES WITH SPECIAL REFERENCE TO THE GASTROINTESTINAL TRACT

\begin{tabular}{|c|c|c|c|c|c|c|}
\hline \multirow[t]{2}{*}{ Case } & \multirow{2}{*}{$\begin{array}{l}\text { Age and } \\
\text { Sex }\end{array}$} & \multirow{2}{*}{$\begin{array}{l}\text { Raynaud's } \\
\text { Phenomenon }\end{array}$} & \multirow{2}{*}{$\begin{array}{l}\text { Skin } \\
\text { Involvement }\end{array}$} & \multirow{2}{*}{$\begin{array}{l}\text { Other Organs } \\
\text { Involved }\end{array}$} & \multirow{2}{*}{$\begin{array}{l}\text { Parts of } \\
\text { Gastrointestinal Tract } \\
\text { Involved }\end{array}$} & Gastrointestinal Tract \\
\hline & & & & & & $\begin{array}{l}\text { Oesophageal } \\
\text { Symptoms }\end{array}$ \\
\hline F.C. & $\begin{array}{l}48 \\
\mathbf{M}\end{array}$ & + & + & Lung & $\begin{array}{l}\text { Oesophagus, stomach, } \\
\text { small bowel, } \\
\text { large bowel }\end{array}$ & None \\
\hline E.N. & $\begin{array}{l}43 \\
F\end{array}$ & + & + & & $\begin{array}{l}\text { Oesophagus, } \\
\text { small bowel }\end{array}$ & Dysphagia \\
\hline M.M. & $\begin{array}{l}67 \\
F\end{array}$ & - & + & & Small bowel & None \\
\hline E.M. & $\begin{array}{l}40 \\
F\end{array}$ & + & + & & $\begin{array}{l}\text { Stomach, } \\
\text { small bowel }\end{array}$ & None \\
\hline E.J. & $\begin{array}{l}44 \\
F\end{array}$ & + & + & $\begin{array}{l}\text { Heart, } \\
\text { kidneys }\end{array}$ & $\begin{array}{l}\text { Oesophagus, stomach, } \\
\text { small bowel, } \\
\text { large bowel }\end{array}$ & $\begin{array}{l}\text { Dysphagia } \\
\text { (stricture present) }\end{array}$ \\
\hline C.D. & $\begin{array}{l}34 \\
F\end{array}$ & + & + & & $\begin{array}{l}\text { Oesophagus, } \\
\text { small bowel }\end{array}$ & None \\
\hline E.C. & $\begin{array}{l}49 \\
\mathrm{~F}\end{array}$ & + & + & & $\begin{array}{l}\text { Oesophagus, } \\
\text { small bowel, } \\
\text { large bowel }\end{array}$ & $\begin{array}{l}\text { Dysphagia } \\
\text { (severe stricture, } \\
\text { gastrostomy) }\end{array}$ \\
\hline I.M. & $\begin{array}{l}61 \\
F\end{array}$ & + & + & & $\begin{array}{l}\text { Oesophagus, stomach, } \\
\text { small bowel, } \\
\text { large bowel }\end{array}$ & Dysphagia \\
\hline L.T. & $\begin{array}{l}67 \\
F\end{array}$ & - & - & & Small bowel & None \\
\hline L.C. & $\begin{array}{l}75 \\
F\end{array}$ & + & + & & $\begin{array}{l}\text { Oesophagus, stomach, } \\
\text { small bowel, } \\
\text { large bowel }\end{array}$ & Dysphagia \\
\hline
\end{tabular}

was present only in E.J. who developed radiological and clinical pyloric stenosis.

Of the five patients with radiological evidence suggestive of gastric involvement three had no upper abdominal symptoms and it seems likely that gastric involvement by itself may produce few symptoms. Involvement of the upper small bowel or of the oesophagus may cause prominent upper abdominal and epigastric symptoms and these may easily overshadow any symptoms of gastric involvement.

In case E.J., whose barium meal was originally normal, changes of pyloric stenosis developed over a period of eight months, while she was already suffering from small and large bowel scleroderma. At operation a partial gastrectomy was carried out and pathological examination showed severe sclerodermatous involvement of the stomach and pylorus. Although there was an ulcer, $1 \mathrm{~cm}$ diameter, in the stomach it was about $2 \mathrm{~cm}$ proximal to the pylorus, and on review of the macroscopic and microscopic appearances it appeared almost certain that the pyloric stenosis was the result of scleroderma rather than due to inflammation around the ulcer.
SMALL BOWEL Small bowel meals were performed in all 10 patients.

In the duodenum, which was visualized in only eight cases, the most striking abnormality was dilatation of the lumen which was present in five cases and was very marked in three. In four patients barium persisted within the duodenum for an abnormally long time although the head of the barium column traversed the duodenum at a normal rate and had reached the caecum in three of the four cases within five to six hours. The duodenal cap in one patient presented a dilated and completely unchanged outline on all the films in the series.

In all 10 cases the jejunum was dilated, especially in its upper part, and in four this appearance was most striking. A characteristic transverse barring of the mucosal pattern with prominent folds running transversely across the whole width of the bowel was also present in all 10 cases (Figs. 1 and 2). In some parts of the jejunum where this appearance was seen, the space between the folds was greater than the width of the folds and in other parts it was less. Another notable feature was that in five of the 10 cases the small bowel tended to run in straight lengths for more than 3 to 4 in. between 
TABLE I-Continued

SUMMARY OF CLINICAL FEATURES WITH SPECIAL REFERENCE TO THE GASTROINTESTINAL TRACT

Gastrointestinal Tract

Cause of

\begin{tabular}{lllll}
\hline $\begin{array}{l}\text { Upper Abdominal } \\
\text { Symptoms }\end{array}$ & $\begin{array}{l}\text { Pseudo Obstruction } \\
\text { of Small Bowel }\end{array}$ & $\begin{array}{l}\text { Intermittent or } \\
\text { Chronic Diarrhoea }\end{array}$ & Malabsorption & $\begin{array}{l}\text { Constipation } \\
\text { Large Bowel }\end{array}$
\end{tabular}

\begin{tabular}{|c|c|c|c|c|c|}
\hline None & None & $\begin{array}{l}\text { Episodes of diarrhoea, } \\
\text { later alternating } \\
\text { diarrhoea and } \\
\text { constipation }\end{array}$ & Present & $\begin{array}{l}\text { Severe constipation } \\
\text { between episodes of } \\
\text { diarrhoea: } t \text { wo episodes } \\
\text { of obstruction }\end{array}$ & $\begin{array}{l}\text { Inhalation of vomit } \\
\text { during Salmonella } \\
\text { s bredeney infection }\end{array}$ \\
\hline $\begin{array}{l}\text { Nausea, vomiting, } \\
\text { distension after meals, } \\
\text { borborygmi }++\end{array}$ & $\begin{array}{l}\text { Lapartomy ior? } \\
\text { subacute small bowel } \\
\text { obstruction }\end{array}$ & Chronic diarrhoea & Present & None & ? Hypokalaemia \\
\hline None & None & None & Present & None & $\begin{array}{l}\text { Marrow failure } \\
\text { (cause unknown) }\end{array}$ \\
\hline None & None & $\begin{array}{l}\text { Bowels open } \\
2-3 \text { times/day }\end{array}$ & None & None & \\
\hline $\begin{array}{l}\text { Discomfort, pain, and } \\
\text { vomiting }++ \\
\text { (pyloric stenosis } \\
\text { found at laparotomy) }\end{array}$ & None & $\begin{array}{l}\text { Episodes of diarrhoea } \\
\text { with intervening } \\
\text { constipation }\end{array}$ & Present & $\begin{array}{l}\text { Severe constipation } \\
\text { with faecal masses } \\
\text { impacted on several } \\
\text { occasions }\end{array}$ & Uraemia \\
\hline None & None & $\begin{array}{l}\text { Episodes of diarrhoea } \\
\text { with intervening } \\
\text { constipation }\end{array}$ & $\begin{array}{l}\text { Stool fat not } \\
\text { estimated }\end{array}$ & $\begin{array}{l}\text { Constipation, palpable } \\
\text { faecal masses in colon }\end{array}$ & \\
\hline $\begin{array}{l}\text { Discomfort, } \\
\text { vomiting }\end{array}$ & $\begin{array}{l}\text { Laparotomy for } \\
\text { episode of ? duodenal } \\
\text { obstruction }\end{array}$ & None & Minimal & None & \\
\hline $\begin{array}{l}\text { Discomfort, pain, } \\
\text { distension after } \\
\text { meals }\end{array}$ & None & None & $\begin{array}{l}\text { Stool fat not } \\
\text { estimated }\end{array}$ & $\begin{array}{l}\text { Chronic severe } \\
\text { constipation, episodes } \\
\text { of large bowel } \\
\text { obstruction by faeces }\end{array}$ & $\begin{array}{l}\text { Haemorrhage from } \\
\text { ulcer in oesophagus }\end{array}$ \\
\hline None & None & None & Present & None & \\
\hline None & None & None & None & $\begin{array}{l}\text { Intractable } \\
\text { constipation, severa } \\
\text { episodes of large bowel } \\
\text { obstruction by faeces }\end{array}$ & Rupture of aorta \\
\hline
\end{tabular}

TABLE II

RESULTS OF INVESTIGATIONS

\begin{tabular}{|c|c|c|c|c|c|c|c|c|c|c|c|c|}
\hline Case & $\begin{array}{l}H b \\
(g \%)\end{array}$ & $\begin{array}{l}\text { ESR } \\
\text { (Westergren } \\
\text { mm/hour) }\end{array}$ & $\begin{array}{l}\text { Serum } \\
\text { Fe } \\
(\mu g \%)\end{array}$ & $\begin{array}{l}\text { Serum } \\
\mathrm{Ca} \\
(\mathrm{mg} \%)\end{array}$ & $\begin{array}{l}\text { Alkaline } \\
\text { Phosphatase } \\
\text { (K.A. units) }\end{array}$ & $\begin{array}{l}\text { Serum } \\
\text { Albumin } \\
(\mathrm{g} \%)\end{array}$ & $\begin{array}{l}\text { Serum } \\
\text { Globulin } \\
(\mathrm{g} \%)\end{array}$ & $\begin{array}{l}\text { Serum } \\
\mathbf{B}_{12} \\
(\mu \mu \mathrm{g} / \mathrm{ml})\end{array}$ & $\begin{array}{l}\text { Serum } \\
\text { Folate } \\
(\text { ng/ml })\end{array}$ & $\begin{array}{l}\text { Stool Fat } \\
\text { Excretion } \\
(\mathrm{g} / 24 \mathrm{hr})\end{array}$ & $\begin{array}{l}\text { Figlu } \\
\text { Excretion }\end{array}$ & $\begin{array}{l}\text { Other Abnormal } \\
\text { Investigations }\end{array}$ \\
\hline F.C. & $14 \cdot 6$ & 4 & $13 \cdot 6$ & & & 3.9 & $2 \cdot 1$ & 100 & & $20 \cdot 5$ & $\begin{array}{l}\text { Marked } \\
\text { excess }\end{array}$ & \\
\hline E.N. & $13 \cdot 3$ & 59 & & $7 \cdot 8$ & & $2 \cdot 0$ & $2 \cdot 5$ & & & $17 \cdot 0$ & No excess & $\begin{array}{l}\text { Delay in excretion of } \\
\text { a water load, persist- } \\
\text { ently low serum } \\
\text { potassium }\end{array}$ \\
\hline M.M. & $12 \cdot 7$ & 26 & & $9 \cdot 2$ & 13 & $4 \cdot 1$ & 3.7 & 190 & $2 \cdot 3$ & $8 \cdot 0$ & $\begin{array}{l}\text { Slight } \\
\text { excess }\end{array}$ & $\begin{array}{l}\text { Schilling test, } 6.5 \% \\
\text { of dose excreted in } \\
24 \mathrm{hr}\end{array}$ \\
\hline E.M. & $13 \cdot 3$ & 5 & & 8.8 & & $4 \cdot 5$ & $1 \cdot 8$ & 220 & & 2.7 & & \\
\hline E.J. & $12 \cdot 6$ & 8 & 52 & $7 \cdot 6$ & 32 & $3 \cdot 2$ & $2 \cdot 3$ & 700 & $4 \cdot 0$ & $23 \cdot 2$ & & $\begin{array}{l}\text { Delay in excretion } \\
\text { of a water load }\end{array}$ \\
\hline C.D. & $10 \cdot 3$ & 119 & 60 & $8 \cdot 5$ & 12 & $3 \cdot 8$ & $7 \cdot 8$ & 120 & 8.5 & & & $\begin{array}{l}\text { Marked increase in } \\
\gamma \text { globulin in serum }\end{array}$ \\
\hline E.C. & $6 \cdot 3$ & 28 & 40 & $8 \cdot 7$ & & $4 \cdot 3$ & $1 \cdot 7$ & 380 & $4 \cdot 0$ & $7 \cdot 4$ & & $\begin{array}{l}\text { Urinary indican } \\
\text { excretion } 63 \mathrm{mg} \text { in } \\
24 \text { hours }\end{array}$ \\
\hline $\begin{array}{l}\text { I.M. } \\
\text { L.T. }\end{array}$ & $\begin{array}{l}10 \cdot 7 \\
15.9\end{array}$ & $\begin{array}{l}42 \\
29\end{array}$ & $\begin{array}{l}35 \\
60\end{array}$ & $\begin{array}{l}9.0 \\
8.4\end{array}$ & 11 & 4.5 & $\begin{array}{l}2.4 \\
2.6\end{array}$ & 180 & $\begin{array}{l}4 \cdot 0 \\
3.5\end{array}$ & & & \\
\hline & & & 60 & $8 \cdot 4$ & 35 & $4 \cdot 3$ & 2.6 & 225 & $3 \cdot 5$ & $15 \cdot 6$ & & $\begin{array}{l}\text { Low serum potassium, } \\
\text { gross radiological } \\
\text { evidence of osteo- } \\
\text { malacia, urinary } \\
\text { indican excretion } \\
86 \mathrm{mg} \text { in } 24 \mathrm{hr}\end{array}$ \\
\hline L.C. & $8 \cdot 2$ & 27 & 96 & $8 \cdot 8$ & & 2.9 & 3.8 & 80 & & 1.6 & $\begin{array}{l}\text { Moderate } \\
\text { excess }\end{array}$ & \\
\hline
\end{tabular}


TABLE III

ABNORMALITIES SEEN ON RADIOLOGICAL EXAMINATION

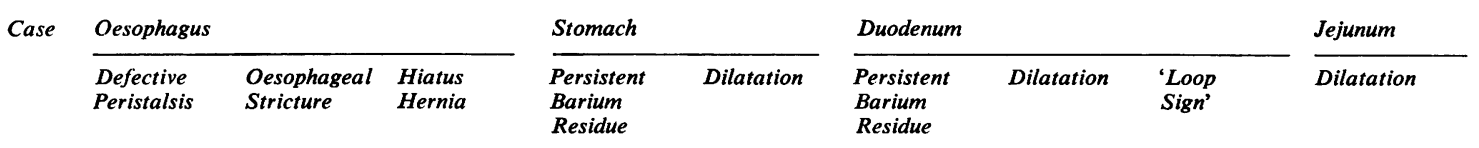

\begin{tabular}{|c|c|c|c|c|c|c|c|c|c|}
\hline F.C. & + & - & - & + & - & - & - & - & ++ \\
\hline $\begin{array}{l}\text { E.N. } \\
\text { M.M. }\end{array}$ & - & - & + & - & - & $\begin{array}{l}+ \\
+\end{array}$ & $\begin{array}{l}++ \\
-\end{array}$ & \pm & $\begin{array}{l}++ \\
+\end{array}$ \\
\hline E.M. & - & - & - & + & - & + & ++ & + & $\begin{array}{l}T \\
+\end{array}$ \\
\hline E.J. & + & + & + & + & + & & & & ++ \\
\hline C.D. & + & - & + & - & - & - & - & - & + \\
\hline E.C. & + & + & + & - & - & & & & + \\
\hline I.M. & + & - & - & + & - & - & + & + & + \\
\hline L.T. & - & - & - & - & - & - & ++ & + & ++ \\
\hline L.C. & + & - & - & + & - & + & + & - & + \\
\hline
\end{tabular}

abrupt changes of direction, and two or three of the straight segments often lay adjacent and parallel to one another. A particularly clear-cut outline to the jejunal shadow was also noticeable in seven patients, the edge of the bowel being particularly well defined.

In three cases part of the ileum was dilated, and in one of these there was transverse barring and straightened loops of bowel. In one further case there was transverse barring.

The overall time taken for the head of the small bowel meal to reach the caecum was noted in eight patients, the longest time recorded being five to six hours.

Small intestinal involvement in this group presented several clinical pictures. In a number of patients, two or more of these manifestations were present at the same time or developed in the course of the disease.

No gastrointestinal symptoms Of our 10 patients four had no symptoms referable to the small intestine although one (case E.M.) had her bowels open two to three times a day, and two others (cases M.M. and L.T.) were found to have steatorrhoea with a normal bowel habit.

Mainly upper abdominal symptoms Four patients suffered from upper abdominal discomfort, pain, distension, bloating, increased borborygmi and flatulence, especially after meals. Intermittent cramping pains, nausea and vomiting also occurred, and anorexia was common. Weight loss was a feature in all of these patients and diarrhoea was also present in two.

Pseudo-obstruction of the small bowel Two patients during the course of their illness had episodes of apparent small bowel obstruction with severe and persistent vomiting, abdominal pain, marked abdominal distension, and $x$-ray evidence of fluid levels and dilatation in the duo- denum or jejunum. In both cases a laparotomy carried out to exclude organic obstruction showed only gross dilatation and atony of the upper small bowel.

Chronic or intermittent diarrhoea Three patients had severe episodes of diarrhoea lasting a few days to a few weeks with alternating periods of more normal stools or of constipation. One patient had severe chronic diarrhoea and another had her bowels open two to three times a day. Three of these five patients had evidence of steatorrhoea.

Malabsorption Steatorrhoea was present at some time in six of the eight patients in whom stool fat excretion was measured. One patient (case L.T.), who was excreting $15.6 \mathrm{~g}$ of fat per day, presented with severe osteomalacia but had no abdominal symptoms or change of bowel habit. Weight loss tended to be most severe in these cases and several developed anaemia or other evidence of malabsorption. Results of these investigations are summarized in Table II.

LARGE BOWEL Barium films of the colon were available in eight of the 10 cases and were judged to be abnormal in five. In four patients the most striking change was a loss of haustrations so that the colon appeared rather smooth in outline (Fig. 3). This appearance was confined to the descending colon in one patient but in the other three it was present throughout the length of the large bowel. The colon was dilated in four patients and in two this appearance was very marked. In two cases kinking of the dilated bowel gave an erroneous impression of areas of localized narrowing. 'Pseudo-diverticulae', as described by Kemp Harper and Jackson (1965), were present in only one case. One patient (case E.J.) showed a markedly narrowed, smooth and rather tube-like outline to the colon at the time of her first barium examination but five years later 
TABLE III-Continued

ABNORMALITIES SEEN ON RADIOLOGICAL EXAMINATION

\begin{tabular}{|c|c|c|c|c|c|c|c|c|c|}
\hline \multicolumn{3}{|l|}{ Jejunum } & \multicolumn{4}{|l|}{ Ileum } & \multicolumn{3}{|l|}{ Colon } \\
\hline $\begin{array}{l}\text { Transverse } \\
\text { Barring }\end{array}$ & $\begin{array}{l}\text { Straightened } \\
\text { Loops }\end{array}$ & $\begin{array}{l}\text { Clearcut } \\
\text { Outline }\end{array}$ & Dilatation & $\begin{array}{l}\text { Transverse } \\
\text { Barring }\end{array}$ & $\begin{array}{l}\text { Straightened } \\
\text { Loops }\end{array}$ & $\begin{array}{l}\text { Time Taken } \\
\text { for Head of } \\
\text { Small Bowel } \\
\text { Meal to } \\
\text { Reach Caecum }\end{array}$ & $\begin{array}{l}\text { Dilatation } \\
m\end{array}$ & $\begin{array}{l}\text { Deficient } \\
\text { Haustrations } \\
\text { and Smooth } \\
\text { Outline }\end{array}$ & $\begin{array}{l}\text { Pseudo- } \\
\text { diverticulae }\end{array}$ \\
\hline+ & + & + & - & - & - & 3-4 hrs & + & - & + \\
\hline+ & - & + & - & + & - & unknown & & & \\
\hline+ & + & + & + & - & - & 4-5 hrs & - & - & - \\
\hline+ & - & - & - & - & - & 4-5 hrs & - & - & - \\
\hline$+t$ & + & + & - & - & - & unknown & - & + & - \\
\hline+ & - & - & + & - & - & $1-2$ hrs & & & \\
\hline+ & + & + & - & - & - & $3-4 \mathrm{hrs}$ & $+t$ & + & - \\
\hline+ & - & - & + & + & + & $3-4 \mathrm{hrs}$ & ++ & + & - \\
\hline+ & + & + & - & - & - & $1-2 \mathrm{hrs}$ & - & - & - \\
\hline+ & - & + & - & - & - & $5-6$ hrs & + & + & - \\
\hline
\end{tabular}

the colon, though still smooth and lacking in haustrations, looked much more normal in calibre.

The main symptom present in four of the five patients with colonic involvement was severe. intractable constipation or periods of constipation alternating with episodes of diarrhoea. In all four patients large faecal masses could be felt at times in the colon and episodes of low colonic obstruction occurred with severe pain and abdominal distension. These episodes of obstruction were due to faecal impaction and could be relieved by enemata. One patient (case E.C.) with well marked $x$-ray changes of bowel involvement had no colonic symptoms.

\section{DISCUSSION}

Oesophageal involvement is common in scleroderma and its clinical features are well known. This paper deals with sclerodermatous involvement of the remainder of the gastrointestinal tract where the clinical presentations are protean and less commonly recognized. In the majority of cases in which scleroderma involves the gastrointestinal tract, a history of Raynaud's phenomenon and some evidence of skin involvement precedes the visceral involvement and is of great help in suggesting the cause of the gastrointestinal symptoms. There have, however, been a number of case reports of bowel involvement in the presence of little or no skin involvement by scleroderma (Hale and Schatzki, 1944; Marshall, 1956; Sommerville, Bargen, and Pugh, 1959; Herrington, 1959; Crown, 1961; McBrien and Lockhart Mummery, 1962).

It seems probable from $x$-ray and pathological studies that scleroderma may involve the stomach in many cases in which gastric symptoms are minimal or absent or where their presence may be overshadowed by the predominance of symptoms from other parts of the gastrointestinal tract. A number of authors have described gastric atony, gastric dilatation, and delayed emptying of the stomach on barium meal examination (Rake, 1931; Goetz, 1945), and Gondos (1960) comments on one case with thickening and marked irregularity of the gastric mucosal folds. In our cases gastric dilatation was not a feature but in several cases a barium residue remained for an abnormal length of time in the stomach and in one true pyloric stenosis developed. We have been unable to find any previous reports of pyloric stenosis occurring as a result of sclerodermatous involvement of the stomach and pylorus.

Involvement of the small bowel by scleroderma was first reported by Kraus (1924). Since then increasing numbers of reports of small bowel involvement have appeared and radiological studies have shown that characteristic changes in the small bowel are common. Reinhardt and Barry (1962) noted dilatation of the duodenal bulb and duodenal loop with retention of barium for up to 24 hours after ingestion. They also noted in five patients a characteristic rather sharp margin extending downwards and slightly laterally to the barium outline of the transverse portion of the duodenum. This 'loop sign' was interpreted as being a manifestation of pressure from the superior mesenteric artery upon the stiffened and thickened wall of the duodenum. Changes in the small bowel mucosal pattern, ineffective peristalsis, and delay in transit of barium and segmental or diffuse dilatation of the small bowel are the most commonly reported radiological abnormalities in the jejunum and ileum (Sommerville et al, 1959; Reinhardt and Barry, 1962).

In the present series dilatation of the duodenal lumen and delay in complete emptying of the duodenum were striking features. The 'loop sign' was present in four cases but in all of these there 


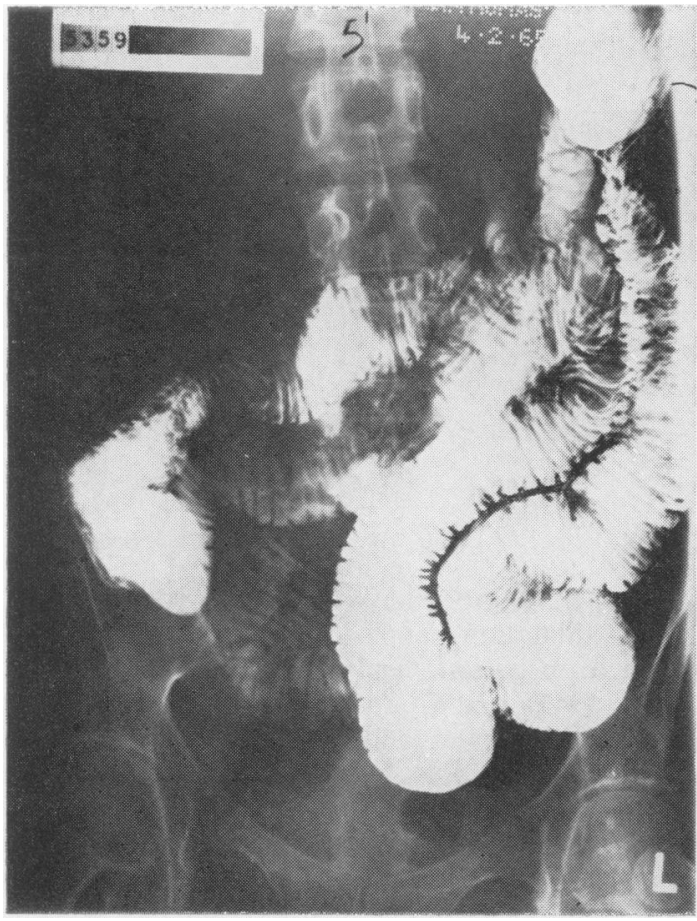

FIG. 1 .

FIG. 1. Small bowel meal (after gastrectomy) showing dilatation of the jejunum and characteristic transverse barring (case E.J.).

FIG. 2. Small bowel meal showing jejunal dilatation, transverse barring, and the tendency for the small bowel to lie in straight lengths between abrupt changes of direction (case M.M.).

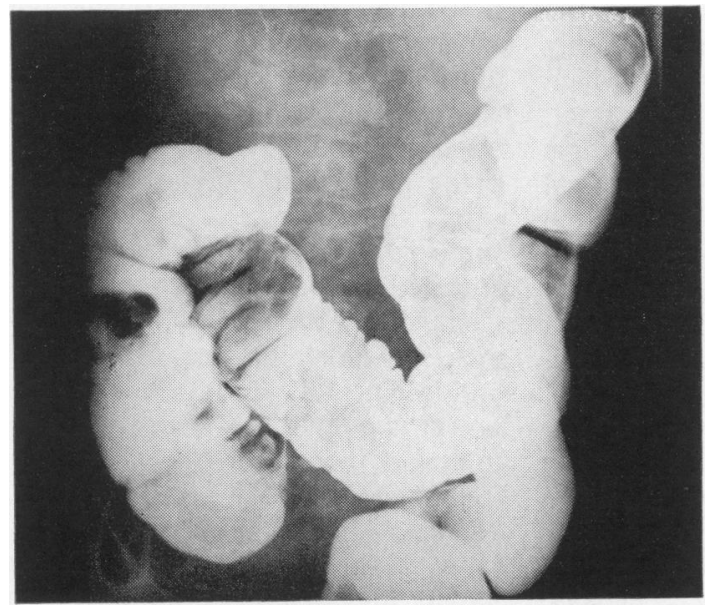

FIG. 3. Barium enema showing colonic dilatation, deficient haustrations, and smooth outline in scleroderma affecting the colon (case L.C.). 
was marked dilatation of the duodenum. It seems likely that the duodenal dilatation accentuates this appearance because of the difference in contrast between the proximal dilated duodenum and the relatively flattened area beneath the superior mesenteric artery. In all of our cases the jejunum was dilated. The characteristic transverse barring seen in all 10 patients was thought to be a consequence of jejunal dilatation and an apparent reorientation of the usual feathery pattern of the mucosal folds, so that they tended to lie in a transverse alignment. The clear-cut outline to the small bowel seen in seven patients is possibly the result of more barium reaching the periphery due to the transverse alignment of the mucosal folds. A tendency for the small bowel to lie in short straight lengths of a few inches between abrupt changes of direction was a striking feature in five patients. This appearance does not seem to have been recorded before but is probably a mechanical effect of the dilated bowel lumen.

Using the dilute barium technique (see above) the head of the barium column reaches the caecum within four hours in $90 \%$ of normal subjects but transit may take up to seven hours in occasional instances. The times taken in eight of our $10 \mathrm{pa}$ tients are shown in Table III, and all appear to be within the limits of normality. In spite of the fact that the head of the barium column passes through the small bowel at a normal speed there is a tendency for some of the barium to remain in parts of the small bowel and this is particularly noticeable in the duodenum so that barium may still be present here many hours after ingestion. Flocculation of barium in the small bowel is not seen with the use of this technique.

A review of clinical case reports in the literature and our own experience in this condition indicates that scleroderma of the small intestine may present any of the clinical pictures outlined previously, and that any case may show one or more of these main manifestations during the course of the disease.

Cases with no symptoms but with radiological evidence of small bowel involvement have been reported by a number of authors (Reinhardt and Barry, 1962; Sackner, 1966) and cases with mainly upper abdominal symptoms have also been frequently described.

In occasional cases a clinical picture of apparent small bowel obstruction has been reported (Marshall, 1956; Herrington, 1959). $X$-ray studies may show fluid levels and dilatation in the duodenum and jejunum, a few sparse bowel sounds may be heard, and the patient appears to have partial ileus or possibly small bowel obstruction. A laparotomy may be performed to exclude organic obstruction of the small bowel but at operation no obstruction is apparent and the small bowel is found to be dilated and atonic. The recognition of this clinical picture in a patient with scleroderma may prevent an unnecessary operation.

Chronic or intermittent diarrhoea may be a prominent feature of small bowel scleroderma. Diarrhoea may persist for months or years at a time or, perhaps, rather more typically, may occur in shortlived episodes lasting from a few days to a few weeks with intervening periods when the stools are more normal. Occasionally, periods of constipation alternate with the episodes of diarrhoea and this pattern was seen in three of our patients, in all of whom the large bowel, as well as the small bowel, was involved.

Malabsorption has been increasingly recognized in recent years and occurs in many, but not in all, patients with diarrhoea. It may also be present in patients with no abdominal symptoms (cases M.M. and L.T.) (Sonneveldt, van Leeuwen, and Blom, 1962). Various explanations have been put forward to explain the malabsorption in these patients but it now seems likely that a change of bowel flora, probably consequent upon stasis in the small bowel, is the most common cause (McBrien and Lockhart Mummery, 1962; Kahn, Jeffries, and Sleisenger, 1966; Salen, Goldstein, and Wirts, 1966; Cliff, Herber, and Demis, 1966). A striking response of diarrhoea and steatorrhoea to broad-spectrum antibiotic therapy was seen in several of our cases, although the involvement was not always so obvious if subsequent courses of treatment were given.

Colonic involvement in scleroderma has usually been reported in association with involvement of the small bowel and there are few reports detailing clinical cases where the colon has been mainly, or solely, affected (Rake, 1931; Lushbaugh, Rubin, and Rothman, 1948; Norton and Monroe, 1962; Hoskins et al, 1962). Kemp Harper and Jackson (1965) summarized the colonic $x$-ray changes in scleroderma. They described wide-necked pseudo-diverticulae, best seen on the antimesenteric border in the transverse and descending colon, and in addition occasional areas of rigidity due to fibrosis which may be present between the sacculations. They also noticed that in advanced cases the pseudo-diverticulae might disappear over the years to be replaced by an atonic and dilated colon. According to these authors replacement of muscle in the colon may be patchy, leading to distension of the fibrous and elastic tissue and the formation of pseudo-diverticulae. As the disease advances the whole wall of the colon may be involved and the localized pseudodiverticulae may disappear to be replaced by generalized dilatation of the colon. 
In the present series the most striking changes seen in the colon were a loss of haustration and localized or generalized dilatation. Pseudo-diverticulae were present in only one patient. It seems probable that the severity of the colonic changes in our cases is, in general, greater than those seen in patients reported in purely radiological series. Although patients with radiological changes in the large bowel do not necessarily have any symptoms referable to the gastrointestinal tract, in cases with severe colonic involvement there is commonly constipation which may be exceedingly chronic and intractable. This picture was seen in two of our cases. In two other cases with radiological changes and, in one further case in which no barium studies of the colon were available, there was severe chronic constipation with occasional episodes of diarrhoea. Episodes of colonic obstruction due to faecal impactation which could be relieved by enemata were a striking feature in several of our patientsa manifestation which has not been emphasized in the literature.

Hoskins et al (1962) have shown that involvement of the colon results in marked decrease in motility as measured by intraluminal pressure techniques. This lack of propulsion seems to be the main cause of the severe and intractable constipation seen in many of these cases. Occasional episodes of diarrhoea are possibly associated with change of bowel flora secondary to stasis in the small bowel or to obstruction with spurious diarrhoea in patients with impacted faeces in the colon.

Cullinan (1953) found that six of 10 patients with scleroderma who were examined by sigmoidoscopy had a peculiar, pale, dry, rather rigid wall to the rectum and lower sigmoid colon which he regarded as the characteristic appearance of sclerodermatous involvement. These typical sigmoidoscopic appearances were present in the only case in which sigmoidoscopy was carried out in the present series and a deep rectal biopsy in this case (E.J.) showed sclerodermatous changes to be severe.

\section{SUMMARY}

The results of investigation and the clinical features in 10 patients with scleroderma involving parts of the gastrointestinal tract other than the oesophagus are reviewed. Five patients had radiological evidence of gastric involvement and one of these developed true pyloric stenosis. Small bowel involvement presented a variety of clinical pictures, including upper abdominal symptoms, pseudoobstruction, chronic or intermittent diarrhoea, and malabsorption. Some cases were asymptomatic.
The large bowel was involved in five patients, and in four of these constipation, either chronic and intractable or alternating with episodes of diarrhoea, was a striking symptom. In all four cases impacted faecal masses in the large bowel led to episodes of partial large bowel obstruction.

Our thanks are due to those members of the staff of St Thomas' Hospital who have kindly allowed us to study their patients.

\section{REFERENCES}

Cliff, I. S., Herber, R., and Demis, D. J. (1966). Control of malabsorption in scleroderma. $J$. invest. Derm. 47, 475-483.

Crown, S. (1961). Visceral scleroderma without skin involvement. Brit. med.J., 2, 1541-1543.

Cullinan, E. R. (1953). Scleroderma (diffuse systemic sclerosis). Proc. roy. Soc. Med., 46, 507-511.

Goetz, R. H. (1945). The pathology of progressive systemic sclerosis (generalised scleroderma). Clin. Proc., 4, 337-392.

Goldgraber, M. B., and Kirsner, J. B. (1957). Scleroderma of the gastrointestinal tract: a review. Arch. Path., 64, 255-265.

Gondos, B. (1960). Roentgen manifestations in progressive sytemic sclerosis (diffuse scleroderma). Amer. J. Roentgenol., 84, 235-247.

Hale, C. H., and Schatzki, R. (1944). The roentgenological appearance of the gastrointestinal tract in scleroderma. Ibid., 51, 407-420.

Harper, R. A. K., and Jackson, D. C. (1965). Progressive systemic sclerosis. Brit. J. Radiol. 38, 825-834.

Herrington, J. L., Jr (1959). Scleroderma as a cause of small-bowel obstruction: successful treatment of a case by intestinal resection. Arch. Surg., 78, 17-24.

Hoskins, L. C., Norris, H. T., Gottlieb, L. S., and Zamcheck, N. (1962). Functional and morphologic alterations of the gastrointestinal tract in progressive systemic sclerosis (scleroderma). Amer. J. Med., 33, 459-470.

Kahn, I. J., Jeffries, G. H., and Sleisenger, M. H. (1966). Malabsorption in intestinal scleroderma. Correction by antibiotics. New Engl. J. Med., 274, 1339-1344.

Kraus, E. J. (1924). Zur Pathogenese der diffusen Sklerodermie. Zugleich ein Beitrag zur Pathologie der Epithelkörperchen. Virchows Arch. path. Anat., 253, 710-734.

Lushbaugh, C. C., Rubin, L., and Rothman, S. (1948). Scleroderma of the intestinal tract: first report of a fatal case. Gastroenterology, $11,382-387$.

McBrien, D. J., and Lockhart Mummery, H. E. (1962). Steatorrhoea in progressive systemic sclerosis (scleroderma). Brit. med. J., 2, 1653-1656.

Marshall, I. (1956). Collagen disease of the small bowel. New Engl. J. Med., 255, 978-983.

Monroe, L. S., and Knauer, C. M. (1962). Gastro-intestinal manifestations of systemic sclerosis (scleroderma). Amer. Practit., $13,636-642$

Norton, R. A., and Monroe, L. S. (1962). The surgical approach to gastrointestinal scleroderma. Report of a case with partial colonic resection. Amer. J. dig. Dis., 7, 766-772.

Rake, G. (1931). On the pathology and pathenogenesis of scleroderma. Bull. Johns Hopk. Hosp.. 48, 212-227.

Reinhardt, J. F., and Barry, W. F., Jr, (1962). Scleroderma of the small bowel. Amer. J. Roentgenol. 88, 687-692.

Rosenthal, F. D. (1957). Small intestinal lesions with steatorrhea in diffuse systemic sclerosis (scleroderma). Gastroenterology, 32, 332-342.

Sackner, M. A. (1966). Scleroderma. Grune and Stratton, New York.

Salen, G., Goldstein, F., and Wirts, C. W. (1966). Malabsorption in intestinal scleroderma. Relation to bacterial flora and treatment with antibiotics. Ann. intern. Med., 64, 834-841.

Sommerville, R. L. Bargen, J. A., and Pugh, D. G. (1959). Scleroderma of the small intestine. Postgrad. Med., 26, 356-364.

Sonneveldt, H. A., van Leeuwen, P., and Blom, P. S. (1962). Malabsorption in acrosclerosis (disseminated scleroderma). Acta med. scand., 171, 391-396. 